\section{The Galliformes are highly threatened: should we care?}

The widespread 'empty forest syndrome' resulting from rampant over-exploitation of animal species for food and trade (Redford, 1992) presents a major challenge to biologists and policy makers involved in conservation. Whilst it is the hunting of large mammals such as elephants and primates in Africa that has received most attention, the likelihood of species extinctions is arguably greater amongst other groups of species and in other regions (see for example Bennett \& Rao, 2002). As pointed out by Milner-Gulland (2002) in a recent editorial in Oryx, the regulation of direct exploitation of species for food and other products by humankind will require that alternative ways are found to secure the livelihoods of those people who are inadvertently causing the crisis. The lack of balance between the maintenance of human livelihoods and the conservation of wildlife is particularly evident in its effects on the status of species in the avian order Galliformes. We think this is no accident; many of these birds have been intimately associated with human communities throughout recorded history.

Nearly 300 species of Galliformes are currently recognized, the major groups being the cracids, grouse, megapodes, partridges and quails, and the pheasants. Collectively they inhabit most terrestrial landmasses apart from the polar extremes. Whilst $11 \%$ of all bird species are currently judged to be at risk of extinction, it is a shock to discover that this includes $25 \%$ of the Galliformes (Hilton-Taylor, 2000). This exceptional level of risk appears in part to be a consequence of the extent to which these birds are hunted or their eggs are collected. Over-exploitation is cited as a problem for $90 \%$ of the threatened species of Galliformes in the five current Action Plans produced by their IUCN Specialist Groups and jointly published by the World Pheasant Association and IUCN in 2000 (http://www.iucn.org/themes/ssc/ actionplans/actionplanindex.htm). Galliformes are preferentially hunted because they are mainly grounddwelling, can occur at high densities, and are generally amongst the largest quarry species available in both open and forested habitats. The megapodes are also exploited for their large yolky eggs, which they bury, sometimes at communal breeding grounds. There are, of course, a number of celebrated cases involving large ground-based species, albeit often flightless ones, being hunted out of existence - the dodo, great auk and moa.
Despite the probable ubiquity of the problem, evidence of a major threat to Galliformes from hunting is usually only circumstantial, not least because this activity is mostly illegal and therefore largely covert. Alarmingly, most of the recent localities of two Endangered species from central Vietnam, Edwards's pheasant Lophura edwardsi and Vietnamese pheasant L. hatinhensis, have been documented following the recovery of birds from snare lines set by rattan collectors. Nevertheless it appears likely that at a global scale species of Galliformes collectively provide one of the most important sources of avian protein in subsistence diets, although in some areas species are now at such reduced densities as a result that they seem unlikely to figure significantly in the bags of hunters.

Several species of Galliformes are vital to local economies and cultural traditions. These include the maleo Macrocephalon maleo, an increasingly threatened megapode from which the eggs are harvested and sold in Sulawesi, Indonesia. In several European countries the male capercaillie Tetrao urogallus is still considered a highly prestigious hunting trophy. Many of these dietary and cultural connections are not new. The cracids, for instance, featured importantly in the Mayan culture of South America, and the tail feathers of the brown eared-pheasant Crossoptilon mantchuricum were worn by Chinese generals, from the time of the Warring States (475-221 BC) until the end of the imperial era in 1911, to symbolise their bravery.

The extinction of any local or global populations of a particular species is obviously a blow to the biodiversity conservation ethic. However, if the species concerned has long been important as a source of food and income, then its demise will only increase the problems that dependant human communities have in meeting their needs for healthy diets and adequate livelihoods, as well as in maintaining their cultural distinctiveness. The current plight of many of the Galliformes exemplifies the direct human-wildlife linkage emphasised by conservationists when seeking support from development agencies, but the ideal of sustainable use seems as difficult as ever to approach, never mind achieve. The importance of wild meat in general, not just Galliformes, in achieving food security is still far from clear (Bennett, 2002).

Central to any efforts to reduce hunting pressure must be a sound understanding of why species are hunted in the first place. Hard facts on this are difficult to come 
by for any threatened species of Galliformes, although the experience of field biologists suggests that human food security itself is not likely to be an important issue. Rather, they cite as the main motivations the provision of a varied diet, cultural traditions, and contributions to subsistence economies. These are the issues that will need to be addressed in the development of realistic solutions for saving species whilst enhancing livelihoods. In developing these solutions it is important to distinguish clearly between the proximate causes of a species' plight, such as availability of guns and snares and access to areas where Galliformes occur, and the underlying causes such as land ownership and land use rights, human population trends and cultural traditions.

It is not only human communities in developing countries that are heavily dependent upon Galliformes for food. Several species are economically important as commercially hunted quarry in developed countries. For instance bobwhite quail Colinus virginianus in the southern USA and ring-necked pheasant Phasianus colchicus as an introduced species in Europe, USA and elsewhere. The annual crop of ruffed grouse Bonasa umbellus in North America exceeds six million, and about 10 million willow grouse Lagopus lagopus are taken from across its circumpolar range. These managed harvests indicate that if appropriate biological, economic and cultural conditions are present then it is possible to ensure that hunted species of Galliformes do not go extinct. This group of birds also includes the wild ancestor of the domestic fowl, which is derived from the red junglefowl Gallus gallus of South and South-east Asia, and the domesticated turkey, originating from the wild turkey Meleagris gallopavo of southern North America. Of course both of these species are now the subjects of huge global industries. It has been estimated that there are perhaps as many as 24 billion chickens on the planet, i.e. one for every four humans! Obviously the gene pools of their wild progenitors remain largely unexploited and must be conserved.

In recognising the importance of animal genetic resources, the Food and Agriculture Organisation of the UN has now established an Intergovernmental Technical Working Group on Animal Genetic Resources (http:/ / dad.fao.org/en/refer/library/reports2/itwg/ itwg2.htm) which is currently overseeing the compilation of the First Report of the State of the World's Animal Genetic Resources. The main focus of this is the conservation of breeds of domesticated animals; the relationship between the domesticated varieties and their wild relatives is not examined in detail. This is surely a gap in the analysis, and there must now be a a strong case for establishing a parallel programme to the proposed Conservation of Wild Relatives of Crop Plants initiative of IUCN. Initially this could be a Task Force comprising those existing IUCN Specialist Groups that cover the wild relatives of pigs, goats, cattle and other domesticated species.

It is clear that an exceptionally high proportion of the Galliformes is threatened with extinction. It is equally plain that these birds have an important place in the diet, culture and commerce of mankind the world over. We therefore believe that they deserve special attention from field biologists, social scientists, conservationists and those in the development sector. These different professions must work together on the problems now confronting them: if we cannot save species that we know for sure are so important to us, what hope is there for the rest?

Philip J.K. McGowan

Conservation Director, World Pheasant Association

P.O. Box 5, Lower Basildon, Reading RG8 9PF, UK

E-mail: conservation@pheasant.org.uk

Peter J. Garson

Chair, WPA/BirdLife/SSC Pheasant Specialist Group

c/o School of Biology, University of Newcastle

Newcastle upon Tyne, NE1 7RU, UK

E-mail: peter.garson@ncl.ac.uk

\section{References}

Bennett, E.L. (2002) Is there a link between wild meat and food security? Conservation Biology, 16, 590-592.

Bennett, E.L. \& Rao, M. (2002) Wild meat consumption in Asian tropical countries: is this a glimpse of the future for Africa? In Links Between Biodiversity Conservation, Livelihood and Food Security: the Sustainable Use of Wild Species for Meat (eds S.A. Mainka \& M. Trivedi), pp. 39-44. IUCN, Gland, Switzerland and Cambridge, UK.

Milner-Gulland, E.J. (2002) Is bushmeat just another conservation bandwagon? Oryx, 36, 1-2.

Redford, K.H. (1992) The empty forest. BioScience, 42, 412-422.

\section{Note from the Editor}

In the July 2001 issue I acknowledged the financial support provided to Oryx by the Rufford Foundation. It is my pleasure to thank them once more, as they have continued their support this year, and also increased it by funding the full-time position of Editorial Assistant.

As you will see from the inside front cover, there have been some changes to the Editorial Board. Dr Mike Maunder of the Fairchild Tropical Garden in Miami has kindly agreed to act as a Senior Editor, bringing a wealth of conservation and botanical experience to the journal, and there are 14 new members of the International Board of Editors. I extend my grateful thanks to those members of the International Board who have stood down; they having provided very valuable support to Oryx over a number of years. 